perception that students go to private universities if they can. In other parts of the United States - notably in the midwestern states - public universities are held in greater esteem and therefore they have wider political support.

Jim Kalas, associate provost for research at SUNY, says the cuts will hit research in three ways: the general atmosphere of retrenchment will encourage the best faculty to leave; $\$ 27$ million used to support graduate students will fund fewer students at higher tuition fees; and there will be no money for new equipment and buildings.

The SUNY board of trustees has drawn up a list of campus and programme closures to meet the Pataki cut. But it has not released it, on the grounds that closure threats would become self-fulfilling. Twothirds of the $\$ 290$ million would be found, the board said, by raising tuition fees by 60 per cent. proposal last week, the board hopes to maximize its leverage in the budget process. Its fears received front page coverage in the state's largest newspaper, Newsday. But Pataki appears to be unmoved, and SUNY officials are privately resigned to a cut of at least US\$200 million.

Colin Macilwain

\title{
NIH to review priorities in readiness for future cuts . . .
}

By publishing its views on the governor's

Washington. Faced by inevitable cuts in spending over the next five years - regardless of which political party is in power the US National Institutes of Health (NIH) are to carry out a wide-ranging review of biomedical research in the United States.

"We will talk to all the universities, to find out how they want biomedical research to look by the year 2000," Harold Varmus, director of the NIH, said in testimony before a congressional committee last week.

Varmus was responding to remarks by John Porter (Republican, Illinois), chairman of the House of Representatives appropriations subcommittee on labour, health and human services, who had just explained that increased spending on health-care and welfare is squeezing out even the highest priority discretionary programmes.

The NIH budget, which stands at $\$ 11.2$ billion this year, with President Bill Clinton having requested $\$ 11.8$ billion for next year, is part of this discretionary spending. Last

\section{. . . as NSF asked how knife could fall}

Washington. The US National Science Foundation (NSF) and its governing board have been asked by a House of Representatives subcommittee how it might absorb a 20 per cent cut in its US $\$ 3.3$ billion budget for the fiscal year 1996, starting on 1 October.

The request was made last week by Jerry Lewis (Republican, California), chairman of the House appropriations subcommittee for Veterans' Affairs, Housing and Urban Development and independent agencies (VA-HUD), to Neal Lane, director of NSF, and Frank Rhodes, chairman of the National Science Board.

Lewis is not yet proposing a 20 per cent cut at the NSF, he said later, but he is asking the foundation to say what it would do to achieve such a cut. Similar requests were being made to other agencies covered by the subcommittee, which is responsible for $\$ 70$ billion - more than a quarter of all nonmilitary money controlled by Congress. Earlier, he had pointed out that NSF's budget had grown by 10 per cent since last year, but he also expressed concern that "very often, science is an easy target for cuts".

In reply, Rhodes told Lewis that the National Science Board, which meets this week, was prepared to help the House set priorities for the NSF. But he said later that he had interpreted Lewis's request as concerning options for 20 per cent savings spread over several years.

But Lewis and his staff say they want ideas on how such a cut could be made in the 1996 budget — and that they need pro- posals by June, when the subcommittee will According to an NSF official, neither the agency nor the board responsible for it is likely to comply with this request; both are expected to tell Lewis that they support the Clinton administration's $\$ 3.3$ billion budget proposal, and that if Congress wants cuts, it itself should decide where to make them.

Lewis said during the hearing that another agency, which he declined to name, had escaped major cuts in the recent rescissions to the 1995 budget because it had cooperated informally with the appropriations subcommittee in setting priorities for future cuts. This was understood to be a reference to the National Aeronautic and Space Administration (NASA), whose administrator, Dan Goldin, has moved swiftly to establish good relations with the new Republican leadership.

Much of the House's NSF appropriations hearing focused on the future of research in Antarctica, where Lewis is worried both by the threatened withdrawal of logistical support from the Department of Defense, and by the estimated $\$ 200$ million cost of a replacement facility at the South Pole.

Joe Knollenberg (Republican, Michigan), was also concerned about NSF's $\$ 600$ million education programmes, and about its support of computer science research which, he implied, was irrelevant when compared to the billions of dollars invested each year by the computer industry itself.

Colin Macilwain help to set the House version of that budget. week's hearing was the first of many at which the NIH will defend the new request.

There is support from both Republicans and Democrats for the NIH's budget, and from Porter in particular, and the institutes are unlikely to be in a worse position under the Republicans than they were before. Porter's subcommittee organized a hearing two weeks ago at which a number of Nobel prize-winners explained the advances that they had made with government support, and the significance of their work to the well-being of the United States today.

The hearing was held partly to put on the record arguments that Republicans wishing to defend the NIH budget will be able to use. But it also gave Porter an opportunity to explain the exigencies of the current budget crisis. He repeated these last week, prompting acknowledgement of the situation from Varmus and his promise that the NIH would examine how biomedical research should accommodate cuts in funding.

Last week, the House Budget Committee entered the fray with its proposal to cut $\$ 100$ billion from discretionary funds at $1995 \mathrm{lev}$ els over the next five years (see previous page). The $\mathrm{NIH}$ would decide the priorities for these cuts, the committee said.

But such priorities would need to be defended. And as Varmus discovered last week, when it comes to specific programmes, agreement between the parties can rapidly break down. Jay Dickey (Republican, Arkansas) asked Varmus how he justified "research into lung cancer and AIDS, diseases brought on by people's own behaviour". Dickey said he needed such justification for the voters in his home constituency.

Varmus argued that behaviour can play a part in most diseases. But Dickey replied that this was not the case in rheumatoid arthritis, and then asked what the NIH was doing about heart disease, an area of research he clearly supports.

Led by Henry Bonilla (Republican, Texas), the subcommittee then became embroiled in a discussion about how many people are killed by AIDS in comparison to other diseases. Bonilla eventually asked Varmus why AIDS is so contentious both among the public and among researchers; it took Varmus a moment of reflection to understand the question, which he then carefully circumnavigated.

To judge by what subcommittee members said, the hearing suggested AIDS research may run into opposition. Yet most of the committee had voted to restore funding for AIDS research cut from the 1995 budget earlier this year. Last week's hearing was the beginning of a long road; as yet, it is hard to see where it is going.

Helen Gavaghan 